\title{
Flammeovirga kamogawensis sp. nov., isolated from coastal seawater in Japan
}

\author{
Shoichi Hosoya and Akira Yokota \\ Institute of Molecular and Cellular Biosciences, The University of Tokyo, Yayoi 1-1-1, \\ Bunkyo-ku, Tokyo 113-0032, Japan
}

Correspondence

Shoichi Hosoya

shouichi.hosoya@mbio.jp
The genus Flammeovirga, belonging to the family 'Flammeovirgaceae' (Garrity \& Holt, 2001), was described by Nakagawa et al. (1997). At present, this genus consists of three species, Flammeovirga aprica (Nakagawa et al., 1997), Flammeovirga arenaria and Flammeovirga yaeyamensis (Takahashi et al., 2006).

In this study, the taxonomic positions of two novel strains, $\mathrm{YS}^{\mathrm{T}}{ }^{\mathrm{T}}$ and YML5, isolated from seawater collected from the Yoshiura coastline (Kamogawa, Chiba Prefecture, Japan) were determined. The sample $(0.05 \mathrm{ml})$ was spread onto plates of SP5 agar [half-strength artificial seawater (ASW; full-strength ASW consists of $3 \% \mathrm{NaCl}(\mathrm{w} / \mathrm{v}), 0.07 \% \mathrm{KCl}$ $(\mathrm{w} / \mathrm{v}), \quad 1.08 \% \mathrm{MgCl}_{2} .6 \mathrm{H}_{2} \mathrm{O}(\mathrm{w} / \mathrm{v}), 0.54 \% \mathrm{MgSO}_{4} .7 \mathrm{H}_{2} \mathrm{O}$ $(\mathrm{w} / \mathrm{v})$ and $\left.0.1 \% \mathrm{CaCl}_{2} \cdot 2 \mathrm{H}_{2} \mathrm{O}(\mathrm{w} / \mathrm{v})\right), 0.9 \%$ Casitone $(\mathrm{w} / \mathrm{v})$, $0.1 \%$ yeast extract $(\mathrm{w} / \mathrm{v})$ and $1.5 \%$ agar $(\mathrm{w} / \mathrm{v})]$ and marine agar 2216 (MA; Difco) and incubated at $15^{\circ} \mathrm{C}$ for a week. The novel agarolytic strains $\mathrm{YS}^{\mathrm{T}} 0^{\mathrm{T}}$ and YML5 were purified and maintained at $25^{\circ} \mathrm{C}$ on marine agar.

The 16S rRNA gene sequences were obtained by direct sequencing of PCR-amplified DNA, as described by Hosoya et al. (2006). The most similar sequences were obtained from the GenBank database using the BLAST program (Altschul et al., 1990). Nucleotide substitution rates $\left(K_{\text {nuc }}\right.$; Kimura, 1980) were determined and a distance matrix tree was constructed using the neighbour-joining method (Saitou \& Nei, 1987) with the CLUSTAL_X program (version 1.83; Thompson et al., 1997). Alignment gaps and unidentified

Abbreviation: ASW, artificial seawater.

The GenBank/EMBL/DDBJ accession number for the 16S rRNA gene sequences of strains $\mathrm{YS} 10^{\top}\left(=\operatorname{IAM} 15451^{\top}=\mathrm{NCIMB} 14281^{\top}\right)$ and YML5 are AB251933 and AB251934, respectively. base positions were not taken into consideration in the calculation. Bootstrap analysis was based on 1000 trials.

The results of the phylogenetic analysis based on 16S rRNA gene sequences showed that strains $\mathrm{YS}^{\mathrm{T}} 0^{\mathrm{T}}$ and YML5 fall into the genus Flammeovirga (Fig. 1). The highest 16S rRNA gene sequence similarity values were found with $F$. aprica (95.0\%), F. arenaria (95.7\%) and F. yaeyamensis (93.5\%). For analysis of genetic relatedness, DNA-DNA hybridization was carried out at $40^{\circ} \mathrm{C}$ for $4 \mathrm{~h}$ and measured fluorometrically using the method of Ezaki et al. (1989). A high level of DNA-DNA relatedness (78-106\%) was found between strains $\mathrm{YS}^{\mathrm{T}} 0^{\mathrm{T}}$ and YML5. The novel isolates showed relatively low DNA-DNA relatedness values with $F$. aprica IAM $14298^{\mathrm{T}}(3.7-5.8 \%)$, F. arenaria NBRC $15982^{\mathrm{T}}(6.5-$ $11.1 \%)$ and F. yaeyamensis NBRC $100898^{\mathrm{T}}(3.8-16.8 \%)$. This is significantly lower than the value generally accepted as the threshold value for the phylogenetic definition of a species (Wayne et al., 1987).

For determination of the $\mathrm{G}+\mathrm{C}$ content, DNA was extracted using the method of Saito \& Miura (1963). The DNA G + C content was determined according to the method of Mesbah et al. (1989). The DNA G+C content of the novel isolates was $32-33 \mathrm{~mol} \%$. The values obtained for the reference strains, F. aprica IAM $14298^{\mathrm{T}}$, F. arenaria NBRC $15982^{\mathrm{T}}$ and F. yaeyamensis NBRC $100898^{\mathrm{T}}$, were $35.6 \mathrm{~mol} \%, 32.7 \mathrm{~mol} \%$ and $35.5 \mathrm{~mol} \%$, respectively.

The following physiological tests were performed. The respiratory quinone was analysed by the method of Komagata \& Suzuki (1987). Growth at different temperatures $\left(8-37^{\circ} \mathrm{C}\right)$, salt tolerance, growth at different $\mathrm{pH}$ values, oxidase and catalase activities, degradation of DNA and alginate and hydrolysis of agar and carboxymethylcellulose 


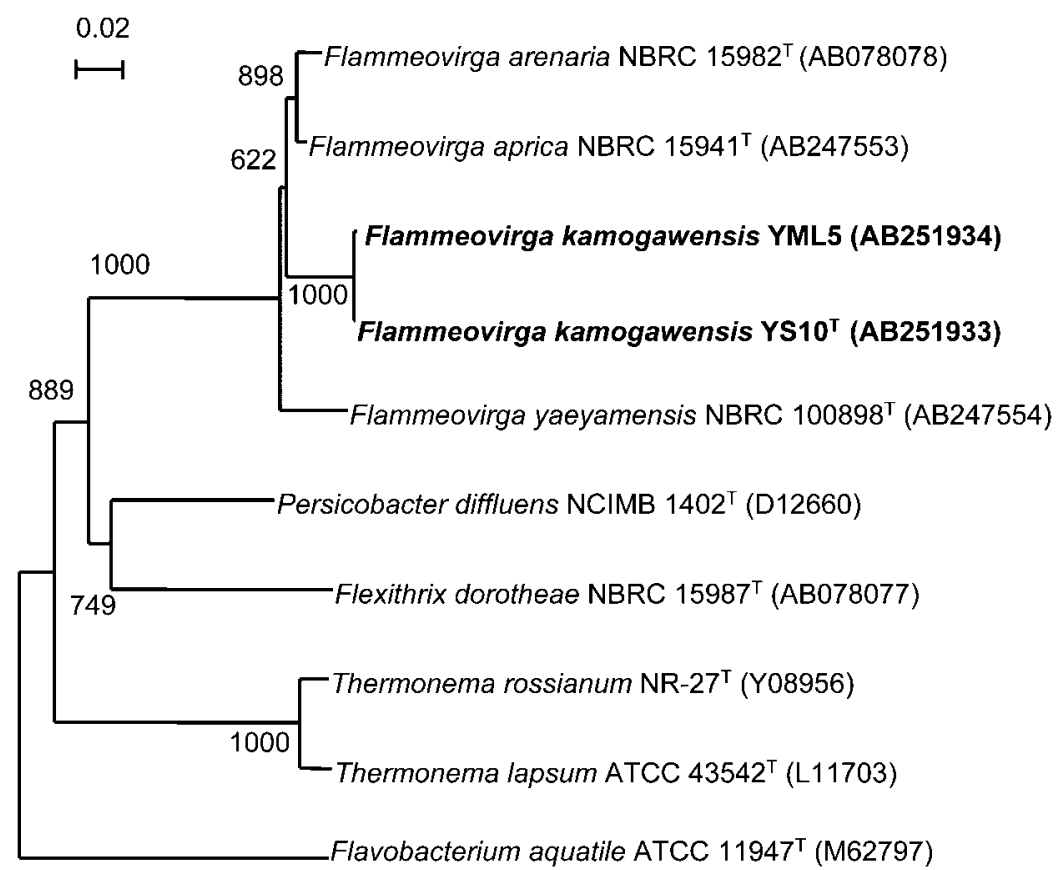

Fig. 1. Neighbour-joining phylogenetic tree showing the position of Flammeovirga kamogawensis sp. nov. and related members of the phylum Bacteroidetes based on $16 \mathrm{~S}$ rRNA gene sequence analysis. Bootstrap values greater than 500 are given at branchpoints. Bar, $0.02 K_{\text {nuc }}$. were determined according to previously described procedures (Hosoya et al., 2006). Degradation of starch was determined using methods described by Smibert \& Krieg (1994). Degradation of Tweens (20, 40, 60 and 80) and L-tyrosine was determined by the methods described by Barrow \& Feltham (1993). Acid production from carbon sources was assessed using modified O/F medium (Nogi et al., 2004). Tests with the API ZYM and API 20E commercial systems (bioMérieux) were generally performed according to the manufacturer's instructions. The API ZYM tests were read after $4 \mathrm{~h}$ incubation at $37^{\circ} \mathrm{C}$ and API $20 \mathrm{E}$ tests were read after $48 \mathrm{~h}$ incubation at $30^{\circ} \mathrm{C}$. Cells for inoculation onto the API test strips were suspended in halfstrength ASW. Cell movement at colony edges was verified by using phase-contrast microscopy. For analysis of cellular fatty acids, cells were grown for $48 \mathrm{~h}$ at $30^{\circ} \mathrm{C}$ on trypticase soy broth (BBL) containing $1.2 \%$ Gellan gum, supplemented with half-strength ASW. Cellular fatty acids were analysed by using the GC-based Microbial Identification system (MIDI).

Strains $\mathrm{YS}^{\mathrm{T}} 0^{\mathrm{T}}$ and YML5 were Gram-negative, aerobic, nonsporulating, non-fruiting, gliding bacteria. The novel isolates formed reddish-orange colonies in the exponential growth phase, but turned white in the late stationary growth phase. Cells were long rods, $0.6-1.0 \mu \mathrm{m}$ wide by $2.0-40 \mu \mathrm{m}$ long. The phenotypic characteristics are given in the species description. Strains $\mathrm{YS}^{\mathrm{T}}{ }^{\mathrm{T}}$ and YML5 can be differentiated from species of the genus Flammeovirga by several characteristics (Table 1). Phenotypic differences between the novel isolates and F. aprica IAM $14298^{\mathrm{T}}$, F. arenaria NBRC $15982^{\mathrm{T}}$ and F. yaeyamensis NBRC $100898^{\mathrm{T}}$ were seen in the degradation of gelatin, activity of esterase (C4), chymotrypsin, $\alpha$-galactosidase, $\beta$-glucuronidase and $\alpha$-glucosidase and acid production from rhamnose and xylose.
On the basis of DNA-DNA hybridization, phylogenetic analysis and phenotypic characteristics, the isolates are proposed as representing a novel species of the genus Flammeovirga, for which the name Flammeovirga kamogawensis sp. nov. is proposed.

\section{Description of Flammeovirga kamogawensis sp. nov.}

Flammeovirga kamogawensis (kamo.ga.wen'sis. N.L. fem. adj. kamogawensis pertaining to Kamogawa, Japan, from where the organisms were isolated).

Table 1. Differential characteristics of strains $\mathrm{YS}_{10}{ }^{\top}$, YML5 and species of the genus Flammeovirga

Species: 1, F. kamogawensis sp. nov. (2 strains); 2, F. aprica IAM $14298^{\mathrm{T}}$; 3, F. arenaria NBRC $15982^{\mathrm{T}} ; 4, \quad$ F. yaeyamensis $\mathrm{NBRC}$ $100898^{\mathrm{T}}$. + , Positive; - , negative.

\begin{tabular}{|lcccc|}
\hline Characteristic & $\mathbf{1}$ & $\mathbf{2}$ & $\mathbf{3}$ & $\mathbf{4}$ \\
\hline Degradation of gelatin & + & - & - & + \\
Activities of: & & & & \\
$\quad$ Chymotrypsin & - & + & + & - \\
$\quad$ Esterase (C4) & - & - & + & - \\
$\quad \alpha$-Galactosidase & - & - & - & + \\
$\quad \alpha$-Glucosidase & - & + & + & - \\
$\quad \beta$-Glucuronidase & - & - & + & - \\
Acid produced from: & & & & \\
$\quad$ Rhamnose & - & - & - & + \\
$\quad$ Xylose & - & + & - & + \\
DNA G+C content $(\mathrm{mol} \%)$ & $32-33$ & 35.6 & 32.7 & 35.5 \\
\end{tabular}


Table 2. Fatty acid profiles of species of the genus Flammeovirga

Species: 1, F. kamogawensis (2 strains); 2, F. aprica IAM $14298^{\mathrm{T}}$; 3, F. arenaria NBRC $15982^{\mathrm{T}} ; 4$, F. yaeyamensis (5 strains; data from Takahashi et al., 2006). Values are percentages $(\mathrm{w} / \mathrm{w})$ of total fatty acids. - , Not detected; tr, trace amount $(<1.0 \%)$.

\begin{tabular}{|lcccc|}
\hline Fatty acid & $\mathbf{1}$ & $\mathbf{2}$ & $\mathbf{3}$ & $\mathbf{4}$ \\
\hline iso-13:0 & $1.9-2.5$ & 3.1 & 2.5 & $1.2-1.5$ \\
$13: 1$ AT 12-13 & $1.6-1.8$ & 2.5 & 2.9 & $0.8-1.5$ \\
iso-14:0 & $4.3-4.8$ & 4.4 & 5.0 & $\operatorname{tr}$ \\
$14: 0$ & $7.8-9.0$ & 6.7 & 4.9 & $3.7-6.2$ \\
iso-15:0 & $21.2-23.0$ & 31.0 & 25.0 & $30.5-54.3$ \\
anteiso-15:0 & $1.5-1.9$ & 1.3 & 2.0 & $1.5-2.6$ \\
$15: 0$ & $6.4-7.1$ & 2.2 & 8.1 & $0.7-2.1$ \\
iso-16:1 H & $0-3.2$ & - & 1.1 & $\operatorname{tr}$ \\
$16: 0$ N alcohol & $1.0-1.1$ & - & 1.8 & $0.3-1.5$ \\
$16: 1 \omega 5 c$ & $4.0-4.7$ & - & 1.8 & $2.7-4.4$ \\
$16: 0$ & $2.8-4.4$ & - & 4.2 & $3.3-4.8$ \\
iso-15:0 3-OH & $4.9-5.0$ & 5.5 & 5.4 & $3.9-5.0$ \\
$15: 03-\mathrm{OH}$ & $2.2-2.6$ & 2.1 & 2.8 & $\operatorname{tr}$ \\
$16: 03-\mathrm{OH}$ & $12.0-14.6$ & 4.1 & 7.7 & $8.4-10.5$ \\
iso-17 $: 03-\mathrm{OH}$ & - & - & - & $2.0-2.4$ \\
$20: 4 \omega 6 c$ & $11.4-12.8$ & 24.7 & 14.4 & $15.0-23.2$ \\
$18: 03-\mathrm{OH}$ & $1.6-1.9$ & - & 3.2 & $0-4.6$ \\
Summed feature $2 *$ & $1.1-2.7$ & 1.4 & - & $\operatorname{tr}$ \\
& & & & \\
\hline
\end{tabular}

*Summed feature 2 contains 14:0 3-OH and/or 16:1 iso I.

Cells are Gram-negative, long rods, $0.6-1.0 \mu \mathrm{m}$ wide by $2.0-40 \mu \mathrm{m}$ long. Motile by gliding. Colonies are reddishorange in the exponential growth phase and turn white in the late stationary growth phase. Cytochrome oxidase activity is variable. Catalase activity is positive. Growth occurs at $15-30{ }^{\circ} \mathrm{C}$; the optimum growth temperature is $30^{\circ} \mathrm{C}$. No growth occurs at either $8{ }^{\circ} \mathrm{C}$ or $37^{\circ} \mathrm{C}$. The $\mathrm{pH}$ range for growth is 6.0-8.0. Growth occurs at $\mathrm{NaCl}$ concentrations of $2-4 \%(w / v)$ on R2A agar. Degradation of agar, alginate, carboxymethylcellulose, DNA, gelatin, starch and Tweens (20, 40 and 60$)$ is positive. Nitrate is reduced to nitrite. Positive for alkaline phosphatase, esterase lipase (C8), leucine arylamidase, valine arylamidase, cystine arylamidase, acid phosphatase, naphthol-AS-BI-phosphohydrolase, $\alpha$-glucosidase and $N$-acetyl- $\beta$-glucosaminidase. Acid is produced from cellobiose, galactose, glucose, lactose, maltose and mannose. Does not decompose citrate, Tween 80 or tyrosine. No production of acetoin, $\mathrm{H}_{2} \mathrm{~S}$ or indole. Negative in tests for arginine dihydrolase, lysine decarboxylase, ornithine decarboxylase, tryptophan deaminase, esterase (C4), lipase (C4), trypsin, chymotrypsin, $\alpha$-galactosidase, $\beta$-galactosidase, $\beta$-glucuronidase, $\beta$-glucosidase, $\alpha$-mannosidase and $\alpha$-fucosidase activities. Does not produce acid from arabinose, dulcitol, fructose, glycerol, inositol, mannitol, raffinose, rhamnose, sorbitol, sucrose, trehalose or xylose. The respiratory quinone is MK-7. The major fatty acids are iso-15:0, 16:0 $3-\mathrm{OH}$ and $20: 4 \omega 6 c$ (Table 2). The DNA G+C content is $32-33 \mathrm{~mol} \%$.

The type strain, YS10 ${ }^{\mathrm{T}}\left(=\operatorname{IAM} 15451^{\mathrm{T}}=\mathrm{NCIMB} 14281^{\mathrm{T}}\right)$, was isolated from coastal seawater off Yoshiura in Kamogawa in Japan.

\section{References}

Altschul, S. F., Gish, W., Miller, W., Myers, E. W. \& Lipman, D. J. (1990). Basic local alignment search tool. J Mol Biol 215, 403-410.

Barrow, G. I. \& Feltham, R. K. A. (1993). Cowan and Steel's Manual for the Identification of Medical Bacteria, 3rd edn. Cambridge: Cambridge: Cambridge University Press.

Ezaki, T., Hashimoto, Y. \& Yabuuchi, E. (1989). Fluorometric deoxyribonucleic acid-deoxyribonucleic acid hybridization in microdilution wells as an alternative to membrane filter hybridization in which radioisotopes are used to determine genetic relatedness among bacterial strains. Int J Syst Bacteriol 39, 224-229.

Garrity, G. M. \& Holt, J. G. (2001). Taxonomic Outline of the Archaea and Bacteria. In Bergey's Manual of Systematic Bacteriology, 2nd edn, vol. 1, pp. 155-166. Edited by D. R. Boone, R. W. Castenholz \& G. M. Garrity. New York: Springer.

Hosoya, S., Arunpairojana, V., Suwannachart, C., Kanjana-Opas, A. \& Yokota, A. (2006). Aureispira marina gen. nov., sp. nov., a gliding, arachidonic acid-containing bacterium isolated from the southern coastline of Thailand. Int J Syst Evol Microbiol 56, 2931-2935.

Kimura, M. (1980). A simple method for estimating evolutionary rates of base substitutions through comparative studies of nucleotide sequences. J Mol Evol 16, 111-120.

Komagata, K. \& Suzuki, K. (1987). Lipid and cell wall analysis in bacterial systematics. Methods Microbiol 19, 161-207.

Mesbah, M., Premachandran, U. \& Whitman, W. B. (1989). Precise measurement of the $\mathrm{G}+\mathrm{C}$ content of deoxyribonucleic acid by highperformance liquid chromatography. Int J Syst Bacteriol 39, 159-167.

Nakagawa, Y., Hamana, K., Sakane, T. \& Yamasato, K. (1997). Reclassification of Cytophaga aprica (Lewin 1969) Reichenbach 1989 in Flammeovirga gen. nov. as Flammeovirga aprica comb. nov. and of Cytophaga diffluens (ex Stanier 1940; emend. Lewin 1969) Reichenbach 1989 in Persicobacter gen. nov. as Persicobacter diffluens comb. nov. Int J Syst Bacteriol 47, 220-223.

Nogi, Y., Hosoya, S., Kato, C. \& Horikoshi, K. (2004). Colwellia piezophila sp. nov., a novel piezophilic species from deep-sea sediments of the Japan Trench. Int J Syst Evol Microbiol 54, 1627-1631.

Saito, H. \& Miura, K. (1963). Preparation of transforming deoxyribonucleic acid by phenol treatment. Biochim Biophys Acta 72, 612-629.

Saitou, N. \& Nei, M. (1987). The neighbor-joining method: a new method for reconstructing phylogenetic trees. Mol Biol Evol 4, 406-425.

Smibert, R. M. \& Krieg, N. R. (1994). Phenotypic characterization. In Manual of Methods for General and Molecular Bacteriology, pp. 607-654. Edited by P. Gerhardt. Washington, DC: American Society for Microbiology.

Takahashi, M., Suzuki, K. \& Nakagawa, Y. (2006). Emendation of the genus Flammeovirga and Flammeovirga aprica with the proposal of Flammeovirga arenaria nom. rev., comb. nov. and Flammeovirga yaeyamensis sp. nov. Int J Syst Evol Microbiol 56, 2095-2100.

Thompson, J. D., Gibson, T. J., Plewniak, F., Jeanmougin, F. \& Higgins, D. G. (1997). The CLUSTAL X windows interface: flexible strategies for multiple sequence alignment aided by quality analysis tools. Nucleic Acids Res 25, 4876-4882. 
Wayne, L. G., Brenner, D. J., Colwell, R. R., Grimont, P. A. D., Kandler, O., Krichevsky, M. I., Moore, L. H., Moore, W. E. C., Murray,

R. G. E. \& other authors (1987). International Committee on
Systematic Bacteriology. Report of the ad hoc committee on reconciliation of approaches to bacterial systematics. Int $J$ Syst Bacteriol 37, 463-464. 